\title{
THREE ASCOCOTYLE COMPLEX TREMATODES (HETEROPHYIDAE) ENCYSTED IN FISHES FROM LOUISIANA, INCLUDING THE DESCRIPTION OF A NEW GENUS ${ }^{1}$
}

\author{
FRANKLIN SOGANDARES-BERNAL \\ and \\ JOHN F. BRIDGMAN, \\ Department of Zoology, Tulane University \\ New Orleans, Louisiana
}

Results of preliminary investigations of heterophyid trematodes encysted in littoral poeciliid and cyprinodont fishes from brackish Lake Pontchartrain, Louisiana, are reported. Infected poeciliids and cyprinodonts form a natural source of infection for wading birds and certain mammals which feed on them. At times low intensities of infection in wild adult birds with the Ascocotyle complex of species, from areas of heavily infected poeciliid and cyprinodont enzoöicity, show that some immunity (age?) factor may be in operation. Evidence of a presumptive immunity was observed by one of us (F.S.) on the west coast of Florida. Nestling birds believed to be about from one to four days old sometimes had a higher intensity of infection with Ascocotyle complex species than their parents. Exposure of cercariae of the Ascocotyle complex of species, when these are known, to sera from naturally infected nestling and adult birds may produce interesting results.

The broad spectrum of definitive hosts of Ascocotyle complex species, coupled with the modern reappearance of uncooked exotic dishes, may eventually cause these trematodes to be of public health importance in this country.

Acknowledgements are extended to $\mathrm{Mr}$. C. W. Philpott, and Dr. B. I. Sundararaj, of our department, for aid in collecting fish intermediate hosts.

Unless otherwise specified, all measurements are in millimeters.

\section{Ascocotyle leighi Burton, 1956}

Second intermediate host in Louisiana.Mollienisia latipinna LeSueur, sail-fin molly (family Poeciliidae).

Location.-In lumen of conus arteriosus and lumen and wall of ventricle of heart.

1 This investigation was supported in part by a grant (G-13000) from the National Science Foundation.
Locality of second intermediate host.-West end of U. S. Highway 11 Causeway, south shore of Lake Pontchartrain, Louisiana; new locality record.

Discussion.-Burton (1956) described this species from specimens collected from the conus arteriosus of Mollienisia latipinna in Florida. He was able to obtain gravid adults from experimental infections in chicks, but was unable to observe the flame cell pattern which in our specimens is $2[(2+2)+(2$ $+2)$ ].

Price (1936) sectioned specimens of $A s$ cocotyle megalocephala Price, 1932, but did not report a membrane surrounding the muscular oral appendage of this species. Metacercariae of Ascocotyle leighi collected from the heart of Mollienisia latipinna from Lake Pontchartrain, Louisiana, were examined microscopically for details of the muscular oral appendage. This appendage seems to be surrounded by a thin, well defined, membrane which is continuous with at least the basal portion of the oral sucker. This membrane is not apparent in whole mounts stained with Delafield's hematoxylin and can best be observed in live material when the tip of the appendage is contracted. When the appendage is relaxed, the surrounding membrane seems to stretch and adhere so closely to the appendage that it is difficult to observe. The overlap of the muscular oral sucker appendage with the pharynx varies as has been clearly pointed out by Martin (1953) and Stunkard and Uzmann (1955) for Parascocotyle lageniformis and Parascocotyle diminuta respectively. Prolonged observations of Ascocotyle leighi metacercariae, under slight coverslip pressure, revealed that the extension of the forebody did not always control the length of the muscular oral appendage. Variation in position of the appendage is due to extension of the appendage as well as contraction of the forebody which in turn 
shortens the distance between the pharynx and oral sucker. The latter factor seems to be the major cause of variation.

The ventrogenital sac wall of metacercariae of Ascocotyle leighi varies in shape. Live metacercariae were observed, under a floated coverslip, to orient the acetabular concavity anteriorly and to clasp the wall of the ventrogenital sac. Repeated observations revealed that this acetabular sucking action modified the shape of the ventrogenital sac wall. Perhaps acetabular manipulations occasionally serve the purpose of ejecting eggs from the ventrogenital sac in gravid worms.

The gonotyl of Ascocotyle leighi is as pictured by Burton (1956). The gonotyl fills most of the ventrogenital sac and appears to be provided, when live material is studied under $1,250 \mathrm{X}$ magnification, with a patch of very minute spines on its ventral surface adjacent to the ventrogenital sac membrane. The gonotylar spines are not visible in specimens stained with Delafield's hematoxylin.

\section{Parascocotyle diminuta}

Stunkard and Haviland, 1924 (Figure 1)

Second intermediate bosts in Louisiana.Cyprinodon variegatus Lacépede, broad killfish, Fundulus grandis (Baird and Girard), chub; Fundulus jenkinsi (Evermann), chub; Lucania parva (Baird and Girard), rain water fish (family Cyprinodontidae); and Mollienisia latipinna LeSueur, sailfin molly (family Poeciliidae); all new host records.

Location.-Gill filaments of all hosts.

Locality, - West end of U. S. Highway 11 Causeway, south shore of Lake Pontchartrain, Louisiana; new locality record.

Discussion.- $P$. diminuta reported here appears to be the same species reported by Stunkard and Uzmann (1955).

Stunkard and Haviland (1924) named and described Parascocotyle diminuta from rats collected at Clason Point, New York. Their specimens had lost some of the oral spines. Later Stunkard and Uzmann (1955) studied the partial life history of a trematode that they believed to be Parascocotyle diminuta. The metacercariae were found in naturally infected Fundulus beteroclitus (Linn.) and Fundulus majalis (Walbaum) collected on the northeastern coast of the United States. Specimens of $F$, beteroclitus from the $P$. diminuta type locality were examined by these authors and were found infected with metacercariae that were identified as $P$. diminuta. Stunkard and $\mathrm{Uz}$ mann (1955) did not mention the establishment of experimental infections of definitive hosts with $P$. diminuta metacercariae collected at the type locality. We assume that the metacercarial cysts studied by these authors were at least dissected, and oral spination and other morphological details observed. The occurrence of intermediate hosts infected with Parascocotyle metacercariae at the type locality lend support to the hypothesis that the species which Stunkard and Uzmann (1955) reported is Parascocotyle diminuta on epizootiological grounds. Hutton and Sogandares (1958) followed the description of Stunkard and Uzmann (1955) when they identified eggproducing adult specimens of $P$. diminuta obtained from a hamster experimentally exposed to metacercariae from the gills of Fundulus similis (Baird and Girard) collected in the vicinity of St. Petersburg, Florida. On physiological and morphological bases, the identification of $P$. diminuta by Hutton and Sogandares (1958) is in accordance with evidence presented by Stunkard and Uzmann (1955). These latter authors were able to obtain gravid adults of $P$. diminuta from rats and hamsters though not from mice or chicks. Chicks proved to be refractory to infection. Specimens of $P$. diminuta from Mollienisia latipinna in Louisiana produced eggs in a mouse but not a hamster. Martin (1953) studied the partial life-history of a trematode that he believed was identical with Parascocotyle lageniformis (Chandler, 1941). $\mathrm{He}$ collected metacercariae from the gills of Fundulus pallidus Evermann in Texas, and obtained gravid adults from experimental infection of chicks. Although Stunkard and Uzmann (1955) reported chicks refractory to infection with $P$. diminuta, they did not state the age or food of the chicks. As is well known new-born chicks are sometimes more susceptible to trematode infections than are older ones. Furthermore, experimental infections of older chicks are sometimes dependent upon diet. Thus, at present we cannot evaluate the physiological 
host-specificity of the two species reported by these authors. Chandler (1941) and Martin (1953) could not have known the details of the oral spination of $P$. diminuta since it was not until 1955 that Stunkard and Uzmann redescribed the species. On morphological grounds there is little doubt that $P$. diminuta Stunkard and Haviland, 1924, and P. lageniformis (Chandler, 1941) are identical. All meristic and morphological characters of the two species appear to overlap. The possibility of morphologically identical physiological strains or species precludes a definite stand regarding the synonymy at this time. We are in agreement with Martin (1953) that Phagicola nana (Ransom, 1921) of Byrd and Reiber (1942) from a Louisiana muskrat is probably $P$. lageniformis, and thus is possibly conspecific with $P$, diminuta. Poeciliid and cyprinodont fishes are frequently found living in the same brackish marshes with muskrats in the New Orleans area. Another view is that $P$. diminuta of Stunkard and Uzmann, 1955, is in reality Parascocotyle lageniformis (Chandler, 1941) and that the taxon Parascocotyle diminuta Stunkard and Haviland, 1924, is a different species. This last possibility is cautiously not subscribed to here. This doubt will always remain because the type material of $P$. diminuta lacks a complete set of oral spines.

Stunkard and Uzmann (1955) reported experimental infections of laboratory-raised Larus argentatus (Linn.) and Nycticorax nycticorax (Linn.). These authors did not state whether their Larus specimen was hatched in the laboratory. One of us (F.S.) found a large percentage of several species of coastal birds with estimated ages of one to four days, infected with trematodes due to feeding of infected food material by their mothers. The Nycticorax apparently infected by Stunkard and Uzmann was a young female captured in Bronx Park, New York. Thus, we do not know if Stunkard and Uzmann actually infected their birds experimentally. The fact remains that these hosts were found infected with $P$. diminuta. Price (1933) reported $P$. diminuta from Butorides. Hutton and Sogandares (1960) reported $P$. diminuta from naturally infected Phalacrocorax auritus floridanus (Audubon) and Hydranassa tricolor ruficollis (Gosse) in Florida. To this list we now add Nycti- corax nycticorax boactli (Gmelin) and Procyon lotor (Linn.) from the west coast of Florida. Mr. Larry Ash, Department of Parasitology, Tulane University, has also given us some specimens of $P$. diminuta collected from a racoon in Louisiana. Thus $P$. diminuta appears to be a polyxenous parasite known to occur naturally in at least two or possibly three unrelated mammals and five or possibly six birds. $P$. diminuta populations from different localities may prove to have developed into "strains" which are identifiable only on a physiological basis. The possibly many faceted physiological host-specificity of $P$. diminuta metacercariae from different intermediate hosts and localities is being investigated further in this laboratory.

Metacercariae of $P$. diminuta collected by us were observed alive under slight coverslip pressure. Cysts in the gill filaments of Fundulus jenkinsi (fig. 1) were 0.136 to 0.200 long and were oval in shape. Cysts from the gills of Mollienisia latipinna were 0.200 to 0.201 long by 0.119 to 0.144 wide The surrounding cyst membranes, gonotyl spination, and flame cell pattern $(2[(2+$ $2)+(2+2)]$ ) are as reported by Stunkard and Uzmann (1955). Mechanically excysted metacercariae have respectively 16 and 2 oral spines in one complete and an incomplete dorsal accessory row. Metacercariae of $P$, diminuta from different intermediate hosts in Louisiana possessed a constant number and arrangement of oral spines.

\section{Pseudascocotyle mollienisicola,}

n. gen., n. sp.

(Figures 2-4)

Second intermediate bost in Louisiana.Mollienisia latipinna LeSueur, sailfin molly (family Poeciliidae).

Location.-Encysted on wall and surface of intestine, body musculature, and on gill branchiae.

Locality of second intermediate host.-West end of U. S. Highway 11 Causeway, south shore of Lake Pontchartrain, Louisiana.

Holotype.-U. S. Nat. Mus. Helm. Coll. No. 39446.

Diagnosis (measurements on 3 gravid specimens, obtained from an experimental hamster infection, killed in boiling water).Body flattened dorsoventrally, pyriform in outline, 0.476 to 0.527 long by 0.221 to 
0.255 wide. Forebody 0.255 to 0.289 long. Cuticle completely spined to level of testes. "Eyespots" present in region of prepharynx and/or pharynx. Oral sucker terminal, with

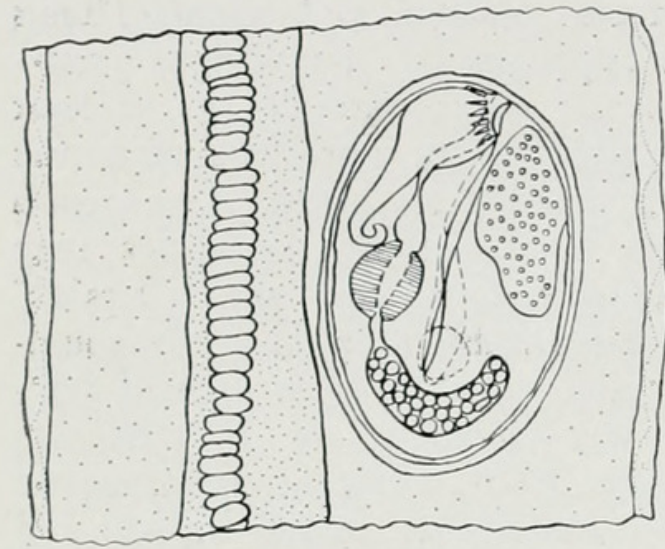

I a rudimentary muscular appendage, lacking oral spines; 0.036 to 0.036 wide by 0.056 to 0.056 from anterior end of sucker to posterior tip of muscular appendage. Pre-
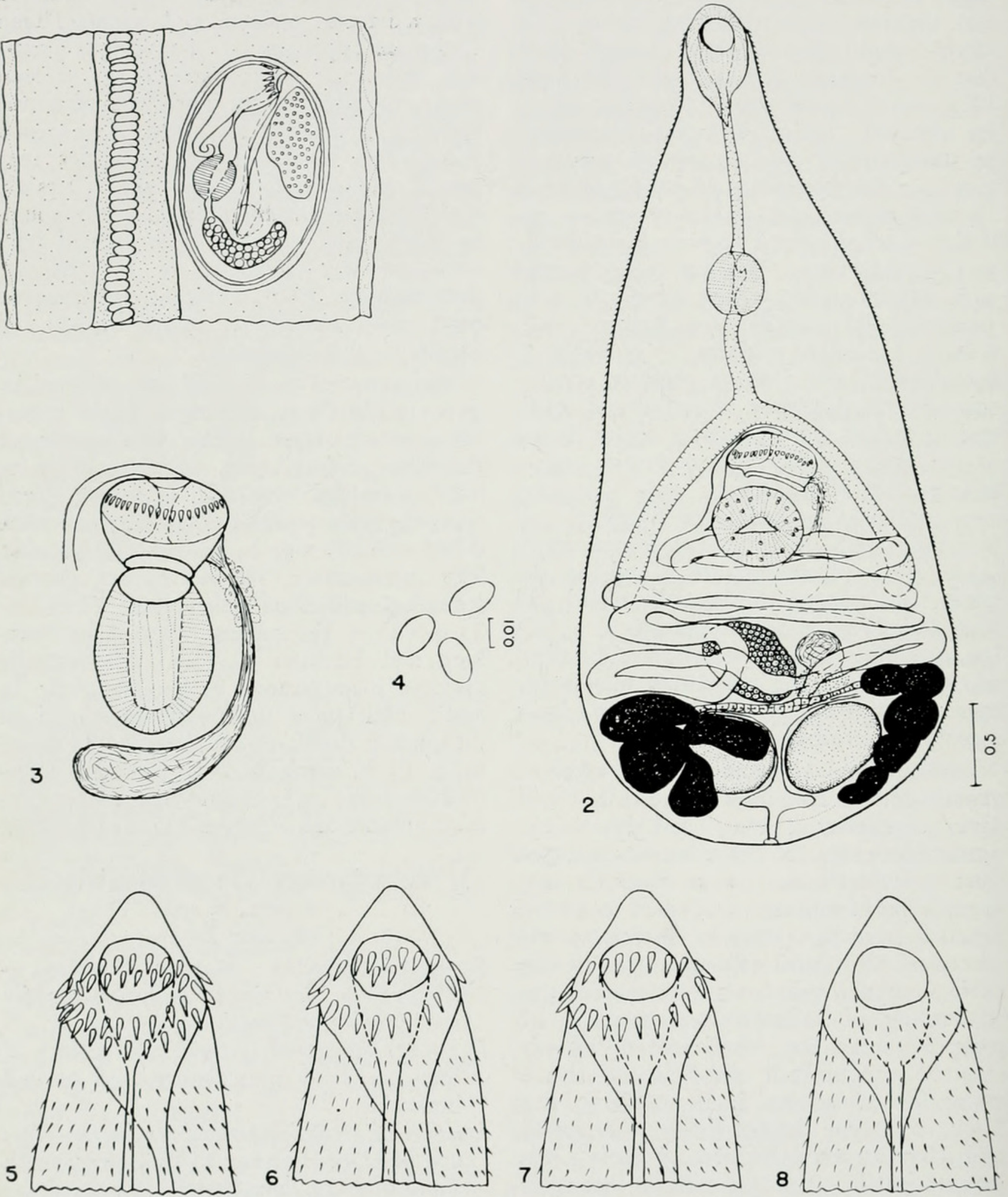

Figures 1-8. 1. Parascocotyle diminuta; metacercaria encysted in gill filament of Fundulus jenkinsi. 2. Pseudascocotyle mollienisicola, sp. nov., ventral view. 3. Same; terminal genitalia and acetabulum oriented anteriorly along longitudinal axis of body. 4. Same; uterine eggs. 5. Ascocotyle, sensu stricto; representative oral and cuticular spination. 6. Parascocotyle, sensu stricto; representative oral and cuticular spination. 7. Phagicola, sensu stricto; representative oral and cuticular spination. 8. Pseudascocotyle, sensu stricto; representative cuticular spination.

Unless otherwise specified, all drawings were made with the aid of a camera lucida. The projected scales have the value in millimeters. 
pharynx inserting ventral to muscular appendage of oral sucker; 0.088 to 0.100 long, or about 1.57 to 1.78 times longer than oral sucker, depending upon contraction of forebody. Pharynx 0.040 to 0.048 long by 0.040 to 0.040 wide. Esophagus from 0.044 to 0.052 long, depending upon contraction of forebody. Ceca 2, connecting with esophagus, one on each side of body, extending a short distance posterior to acetabulum. Acetabulum 0.048 to 0.048 long by 0.056 to 0.056 wide. Sucker width ratio about $1: 1.4$.

Ventrogenital pore median followed by a ventrogenital sac with a gonotyl about 0.012 to 0.016 long by 0.044 to 0.048 wide at its anterior border. Gonotyl with a ventral set of 17 conspicuous spines arranged equatorially in a transverse row. Testes 2 , in posterior $1 / 4$ body, side by side; sinistral testis 0.048 to 0.064 long by 0.048 to 0.072 wide; dextral testis 0.064 to 0.064 long by 0.056 to 0.076 wide. Seminal vesicle saccular, extending from a short distance posterior to acetabulum to insert on sinistral side of ventrogenital sac at level of posterior border of gonotyl where it is surrounded by prostate cells. Ovary between acetabulum and testes, displaced to right of body midline; oval in shape, 0.056 to 0.076 long by 0.068 to 0.076 wide. Seminal receptacle equatorial and sinistral to ovary. Mehlis' gland amid ovary, seminal receptacle, and sinistral testis. Oviduct (visible in live metacercariae) ciliated. Vitelline glands of coarse follicles, usually dorsal and ventral to outer aspect of testes, extending from behind testes to level of ovary. Vitelline duct between testes and ovary, expanding to form a small vitelline receptacle at level of Mehlis' gland. Uterus in transverse coils, restricted between testes and cecal bifurcation, approaching ventrogenital sac on dextral side to insert into anterior border where it perforates the gonotyl to open on its median posterior border as a uterine pore. Eggs (fig. 4) 0.016 to 0.020 long by 0.012 to 0.012 wide. Excretory vesicle extending from a median posterior excretory pore, between testes, usually following their contour, to end on anterior aspect of testes; excretory ducts branching at level of or slightly anterior to acetabulum; flame cell formula $2[(2+2)+(2+2)]$.

Generic diagnosis of Pseudascocotyle.-
Small heterophyid trematodes with a dorsoventrally flattened pear-shaped body. "Eyespots" present. Cuticle spined. Oral sucker terminal, lacking spines, with a rudimentary muscular appendage. Prepharynx, pharynx, and esophagus present. Ceca 2, one on each side of body, terminating a short distance posterior to equator. Acetabulum present. Ventrogenital pore immediately anterior to acetabulum, followed by an anteriorly directed ventrogenital sac bearing, on its anterior portion, a prominent gonotyl which is transversely spined at its equator. Testes 2, side by side, in posterior end of body. Seminal vesicle non-muscular, saccular, extending from a short distance behind acetabulum to insert sinistrally on ventrogenital sac at level of posterior border of gonotyl; surrounded by prostate cells at junction with ventrogenital sac. Ovary between acetabulum and testes, slightly displaced to right of body midline. Seminal receptacle adjacent and sinistral to ovary. Mehlis' gland amid ovary, seminal receptacle, and sinistral testis. Oviduct ciliated (in metacercaria). Vitelline glands composed of coarse follicles, extending from behind testes to level of ovary, overlapping testes dorsally and ventrally on their anterior course; vitelline reservoir at level of Mehlis' gland. Uterus confined between pretesticular area and cecal bifurcation, approaching ventrogenital sac on its dextral side, entering sac anteriorly where it penetrates the gonotyl to open on its median posterior border. Eggs small, thin shelled. Excretory vesicle extending from terminal excretory pore, intertesticular, usually following contour of testes on its anterior extent, to end on anterior aspect of testes; excretory ducts branching in region of acetabulum; flame cell formula $2[(2+$ $2)+(2+2)]$.

\section{Type species. - Pseudascocotyle mollienisi- cola.}

Discussion. - The genus Pseudascocotyle is most closely related to the heterophyid genera Ascocotyle Looss, 1899, Phagicola Faust, 1920, and Parascocotyle Stunkard and Haviland, 1924, but differs by possessing a gonotyl that is perforated by the uterus, and by lacking oral spines. Pseudascocotyle seems to be most closely related to Phagicola and Parascocotyle in that the vitellaria extend to the level of the ovary.

The lack of oral spines in Pseudascocotyle 
was at first believed to represent an artifact when adults were removed from an experimental hamster infection. Studies of the metacercariae soon removed these doubts. Cuticular spines, which in most species of Ascocotyle, Phagicola, and Parascocotyle begin a short distance posterior to the crown spines, leaving a bare zone, extended almost to the oral sucker aperture in our specimens of Pseudascocotyle. We have not made an exact count of sailfin mollies found infected but the incidence is high, at least 95 percent. Sailfin mollies of $23 \mathrm{~mm}$ total length were infected.

The following artificial key will serve to separate the four genera of the Ascocotylinae Yamaguti, 1958, as we presently visualize the subfamily.

1. Oral sucker with one or more circlet(s) of spines (figs. 5 to 7 ); vitellaria extending either to level of ovary or to acetabulum

Oral sucker lacking spines (fig. 8); vitellaria extending to level of ovary

Pseudascocotyle, (this paper)

2. Oral sucker with two complete circlets of spines (fig. 5) ; vitellaria usually extending to level of acetabulum

Ascocotyle, sensu stricto

Oral sucker never with two complete circlets of spines (figs. 6 to 7 ); vitellaria never extending to acetabulum

3. Oral sucker with a single complete circlet of spines and an incomplete accessory dorsal row of from 2 to 4 spines (fig. 6) ; vitellaria extending to level of ovary

Parascocotyle, sensu stricto

Oral sucker with a single complete circlet of spines (fig. $7)$; vitellaria extending to level of ovary

Phagicola, sensu stricto

\section{The ASCOCOTYLE COMPleX}

The heterophyid trematodes of the genera Ascocotyle Looss, 1899, Phagicola Faust, 1920, Parascocotyle Stunkard and Haviland, 1924, and Pseudascocotyle (this paper) are collectively known as the Ascocotyle complex. Species of the Ascocotyle complex were placed in the heterophyid sub-families Centrocestinae Looss, 1899, by Price (1940) and Ascocotylinae Yamaguti, 1958, by Yam- aguti (1958), though the premetacercarial stages are unknown.

The status of the various genera or subgenera of Ascocotyle complex species has been much disputed by several recent authors. At least three different views have developed in connection with generic or sub-generic designation of the species groups. Price $(1932,1936)$ retained the forms with two complete rows of oral spines in the genus Ascocotyle. He reserved the genus Phagicola for those species with a single and/or second dorsal incomplete row of oral spines. This view seemingly received support from Martin (1951, 1953) and others. Stunkard and Uzmann (1955) reviewed the literature concerning Ascocotyle complex species, and maintained that Parascocotyle is a synonym of Phagicola and that the latter is a subgenus of Ascocotyle. Yamaguti (1958) disregarded the number of rows of oral spines and relied upon a character that almost always coincides with oral spination, the anterior vitelline extent, to separate Ascocotyle from Phagicola. According to Yamaguti (1958), Parascocotyle is a synonym of Phagicola. Burton (1958) recognized Ascocotyle and Phagicola. Almost simultaneously with the appearance of Yamaguti's volume I (1958), Hutton and Sogandares (1958) arrived at conclusions somewhat similar to his except for regarding Parascocotyle a valid genus. Hutton and Sogandares (1958, 1959) used the anterior vitelline extent only to separate Ascocotyle from Phagicola and Parascocotyle. The use of the anterior vitelline extent was nothing new since Witenberg (1929) had used this character to separate Parascocotyle from Ascocotyle. Witenberg considered Phagicola a synonym of Parascocotyle, but Price (1932) clearly pointed out that Phagicola has date priority. From the systematic point of view there appear to be four species groups in the Ascocotyle complex. Ascocotyle angeloi Travassos, 1928 , possesses intergrading characters (2 complete rows of oral spines and vitellaria to ovary) between Ascocotyle, sensu stricto, (forms with 2 complete rows of oral spines and vitellaria usually extending to level of acetabulum), Phagicola, sensu stricto, (forms with 1 complete row of oral spines and vitellaria extending to level of ovary), Parascocotyle, sensu stricto (forms with one com- 
plete row plus one incomplete dorsal accessory row of oral spines and vitellaria extending to level of ovary), and Pseudascocotyle (forms lacking oral spines and vitellaria extending to level of ovary). Within a phylogenetic scheme, $A$. angelo $i$ would tend to reinforce the closeness of relationship between Ascocotyle, Phagicola, Parascocotyle, and Pseudascocotyle. Another view is that Ascocotyle, Phagicola, Parascocotyle, and Pseudascocotyle are sub-genera of Ascocotyle.

Schiller (1957) X-irradiated eggs of $\mathrm{Hy}$ menolepis nana (Siebold, 1852) to demonstrate that the rostellar hooks of this cestode seem to be a stable meristic character. Possibly this stability may apply to the oral spines of certain trematodes under normal conditions. Examinations of several hundred specimens of certain Ascocotyle complex species by one of us (F.S.) seems to bear out this point. Wolfgang (1955) did not find a stability of numbers or number of rows in the oral spines of the acanthocolpid trematode Stephanostomum baccatum (Nicoll, 1907) from several hosts in Canada. This variation observed by Wolfgang (1955) possibly may be attributed to a study of worms from abnormal hosts or from superinfections, though he does not make clear the hosts and the intensities of infections from which the abnormal trematodes were taken. Such great variations in oral sucker spination certainly have not been observed by one of us (F.S.) in many specimens of several Stephanostomum species collected in the tropical American Atlantic and Pacific.

The structure of the terminal genitalia of Ascocotyle complex species has not been used as a device to separate species groups. The terminal genitalia have rarely been described in detail because these structures are difficult to observe even with the best optical equipment. The gonotyl of Ascocotyle complex species is variable in spination, shape, and structure. The gonotyl may possess spines or refractile chitin-like bars. These spines or bars are difficult to observe in stained whole mounts, though they are rather easily observed in live specimens. Apparently no spines or bars have been previously reported from the gonotyl of species of Ascocotyle sensu stricto. Metacercariae of Ascocotyle leighi Burton, 1956, from the heart of Mollienisia latipinna Le Sueur in Louisiana, Parascocotyle diminuta Stunkard and Haviland, 1924 from the gills of Fundulus similis (Baird and Girard) in Florida, Fundulus jenkinsi (Evermann), Fundulus grandis (Baird and Girard), Lucania parva (Baird and Girard), and Cyprinodon variegatus, Lacepede in Louisiana, and Phagicola longa (Ransom, 1920) from the pericardial membrane of Mugil cephalus Linn. and $M u$ gil curema Cuv. and Val. in Florida, were observed for details of the gonotyl. As previously mentioned, very fine gonotyl spines appeared to be present in the gonotyl of Ascocotyle leighi. Parascocotyle diminuta possess gonotylar spines as reported by Stunkard and Uzmann (1955). The gonotyl of Phagicola longa possesses chitin-like bars or rodlets. The gonotyl of Pseudascocotyle (this paper) has been described above. The gonotyl of Ascocotyle, Phagicola, and Parascocotyle is apparently not perforated by the terminal genital ducts, whereas the uterus appears to perforate the gonotyl of Pseudascocotyle.

Ascocotyle complex species have one detail in common; they all possess a characteristic muscular oral sucker appendage that is not found in other heterophyid trematodes. The flame cell pattern of the metacercariae of certain Ascocotyle, Phagicola, Parascocotyle, and Pseudascocotyle, species which we have observed in Florida and Louisiana is $2[(2+2)+(2+2)]$. This flame cell pattern corresponds with that of Centrocestus armatus (Tanabe, 1922) and Centrocestus formosanus (Nishigori, 1924) as reported by Yamaguti (1938) and Martin (1958) respectively. Centrocestus Looss, 1899 is the type genus of the Centrocestinae Looss, 1899. Other Centrocestinae with a flame cell pattern of $2[(2+2)+(2+2)]$ include the genera Pygidiopsis Looss, 1907 and Pygidiopsoides Martin, 1951. Martin (1951) included Caimanicola Freitas and Lent, 1938 and Lacerdaia Travassos, 1931 in the Centrocestinae although Price (1940) had previously pointed out that the genus Caimanicola is a synonym of Acanthostomum Looss, 1899 (family Acanthostomidae Poche, 1926). One of us (F.S.) agrees with this synonymy, having examined 2 immature specimens of what appears to be the same species collected from the type host, Caiman sclerops Gray, in Pirre River, Darien 
Province, Panama. The genus Lacerdaia apparently is related to Pygidiopsis and Pygidiopsoides, though a further study of the terminal genitalia of the first would be necessary to evaluate this point. We do not agree with Yamaguti (1958) in establishing a new subfamily for Pygidiopsis, and in placing Pygidiopsoides in the Haplorchinae Looss, 1899, and Lacerdaia in the Opisthometrinae Yamaguti, 1958. Everything we presently know about these genera seems to indicate that they are closely related. Until further studies prove otherwise, we shall retain the subfamily Centrocestinae for those genera (Centrocestus Looss, 1899, Pygidiopsis Looss, 1907, Pygidiopsoides Martin, 1951, and Lacerdaia Travassos, 1931) possessing an oral sucker without a muscular appendage and shall tentatively allocate the entire Ascocotyle complex of species to the Ascocotylinae Yamaguti, 1958. The Ascocotylinae are similar to the Centrocestinae, though differ in details of terminal genitalia and mainly by possessing an oral sucker with a muscular appendage. If a muscular appendage is found on the oral sucker of cercariae of Ascocotyle complex species, it would at present appear to further strengthen the concept of a separate subfamily for this group of species. The cercariae of Ascocotyle complex species may be of the opthalmopleurolophocercous type with an oral sucker bearing a reduced muscular appendage, a non-cellular excretory vesicle, a flame cell pattern of $2[(2+2)+$ $(2+2)]$, and a number and arrangement of oral spines characteristic of the genus and species represented.

\section{SUMMARY}

1. The following heterophyid (Ascocotylinae Yamaguti, 1958) trematodes are reported for the first time from Louisiana: Ascocotyle leighi Burton, 1956; Parascocotyle diminuta Stunkard and Haviland, 1924; and Pseudascocotyle mollienisicola (this paper).

2. New second intermediate host records include: Parascocotyle diminuta in Cyprinodon variegatus Lacepede, Fundulus grandis (Baird and Girard), Fundulus jenkinsi (Evermann), Lucania parva (Baird and Girard) (family Cyprinodontidae); and Mollienisia latipinna Le Sueur (family Poeciliidae).

3. Additional anatomical details of Asco- cotyle leighi encysted in the type host, Mollienisia latipinna Le Sueur from Louisiana, are described. These include the apparent presence of a patch of very minute spines on the ventral aspect of the gonotyl proximal to the ventrogenital sac, and a flame cell pattern of $2[(2+2)+(2+2)]$.

4. A new genus, Pseudascocotyle, is named for the new species $P$. mollienisicola found encysted in Mollienisia latipinna. Pseudascocotyle differs from other genera in the Ascocotylinae Yamaguti, 1958, by lacking oral spines in both the metacercariae and adults and by possessing a gonotyl perforated by the uterus.

5. Gravid specimens of Ascocotyle leighi and Pseudascocotyle mollienisicola were obtained by feeding metacercariae to a laboratory-raised hamster. Parascocotyle diminuta developed to maturity and produced eggs in an experimentally infected laboratory mouse but not in a hamster.

6. The present status of the Ascocotyle complex of species is discussed and the subfamily Ascocotylinae Yamaguti, 1958 is recognized. We suggest that cercariae of the Ascocotyle complex may be of the opthalmopleurolophocercous type with a reduced muscular oral appendage, a non-cellular excretory vesicle, a flame cell pattern of $2[$ ( 2 $+2)+(2+2)]$ and numbers and row $(\mathrm{s})$ of oral spines corresponding to the species represented.

\section{REFERENCES Cited}

Burton, P. 1956. Morphology of Ascocotyle leighi n. sp. (Heterophyidae), an avian trematode with metacercariae restricted to the conus arteriosus of the fish Mollienesia latipinna Le Sueur. Jour. Parasit., 42: 540-543.

1958. A review of the trematode genera Ascocotyle (Looss) and Phagicola (Faust) of the family Heterophyidae. Proc. Helm. Soc. Wash., 25: 117122.

BYRD, E. and R. J. ReIBER 1942. Mammalian trematodes II. Three flukes from small mammals. Jour. Tenn. Acad. Sci., 17: 143-148.

Chandler, A. C. 1941. Helminths of muskrats in southeast Texas. Jour. Parasit., 27: 175-181.

Hutton, Robert F. and F. SOgandaresBERNAL 1958. Variation in the number of oral spines of Phagicola longicollis Kuntz and Chandler, 1956, and the description of $P$. inglei n. sp. (Trematoda: Heterophyidae). Ibid., 44: 627-632. 
1959. Further notes on Trematoda encysted in Florida mullets. Quart. Jour. Fla. Acad. Sci., 21: 329-334.

1960. Studies on helminth parasites from the coast of Florida II. Digenetic trematodes from shore birds of the West Coast of Florida. 1. Bull. Mar. Sci. Gulf and Carib., 10: 40-54.

Martin, W. E. 1951. Pygidiopsoides spindalis n. gen., n. sp. (Heterophyidae:Trematcda), and its second intermediate host. Jour. Parasit., $37: 297-300$.

1953. Redescription of Phagicola lageniformis Chandler (Trematoda: Heterophyidae) and ob ervztions on part of its life cycle. Thapar Comm. Volume (India): 201-208.

1958. The life histories of some Hawaiian heterophyid trematodes. Jour. Parasit., 44: 305-323.

Price, E. W. 1932. On the genus Phagicola Faust, 1920. Ibid., 19: 166-167.

1933. New host records for trematodes of the genus Phagicola. Ibid., 20: 11 .

1936. A new trematode of the genus Ascocotyle (Centrocestinae). Proc. Helm. Soc. Wash., 3: 31-32.

1940. A review of the trematode superfamily Opisthorchioidea. Ibid., 7: 1-13.

SCHILlER, E. 1957. Investigations on the use of $\mathrm{X}$-irradiation as a mechanism for facilitating the study of morphological variation in Hymenolepis nana. Jour. Parasit., 43 (abstract) : 23.

Stunkard, H. W. and C. B. Haviland 1924. Trematodes from the rat. Amer. Mus. Novitates., No. 126: 1-10.

Stunkard, H. W. and J. R. UzmanN 1955. The killifish, Fundulus heteroclitus, second intermediate host of the trematode,
Ascocotyle (Phagicola) diminuta. Biol. Bull., 109: 475-483.

Witenberg, G. 1929. Studies on the trematode family Heterophyidae. Ann. Trop. Med. Parasit., 23: 131-239.

Wolfgang, R. W. 1955. Studies of the trematode Stephanostomum baccatum (Nicoll, 1907) III. Its life cycle. Canad. Jour. Zool., 33: 113-128.

Yamaguti, S. 1938. Zur Entwicklungsgeschichte von Centrocestus armatus (Tanabe) mit besonderer Berucksichtigung der Cercarie. Zeitsch. Parasitenk., 10: $253-296$.

\section{Systema Helmin-} thum. Vol. I. Digenetic Trematodes. Part 1. Interscience Publishers, N. Y. $979 \mathrm{pp}$.

\section{ABSTRACT}

The trematodes Ascocotyle leighi Burton, 1956; Parascocotyle diminuta Stunkard and Haviland, 1924 and Pseudoscocotyle mollienisicola n. gen., n. sp., (Ascocotlyinae: Heterophyidae) were found encysted in poeciliid and cyprinodont fishes from brackish-water Lake Pontchartrain, Louisiana, All trematode species collected represent new locality records. New second intermediate host records include Parascocotyle diminuta in Cyprinodon variegatus Lacépède, Fundulus grandis (Baird and Girard), Fundulus jenkinsi (Evermann), Lucania parva (Baird and Girard), and Mollienisia latipinna Le Sueur. Previously unknown anatomical details are given for Ascocotyle leighi. Metacercariae of all species reported were fed to experimental definitive hosts and mature trematodes were obtained. The present status of the Ascocotylinae is discussed. 


\section{$2 \mathrm{BHL}$ Biodiversity Heritage Library}

1960. "Three Ascocotyle complex trematodes (Heterophyidae) encysted in fishes from Louisiana, including the description of a new genus." Tulane studies in zoology 8, 31-39. https://doi.org/10.5962/bhl.part.10069.

View This Item Online: https://www.biodiversitylibrary.org/item/25462

DOI: https://doi.org/10.5962/bhl.part.10069

Permalink: https://www.biodiversitylibrary.org/partpdf/10069

\section{Holding Institution}

Harvard University, Museum of Comparative Zoology, Ernst Mayr Library

\section{Sponsored by}

Harvard University, Museum of Comparative Zoology, Ernst Mayr Library

\section{Copyright \& Reuse}

Copyright Status: In copyright. Digitized with the permission of the rights holder.

Rights Holder: Tulane University

License: http://creativecommons.org/licenses/by-nc-sa/3.0/

Rights: https://biodiversitylibrary.org/permissions

This document was created from content at the Biodiversity Heritage Library, the world's largest open access digital library for biodiversity literature and archives. Visit BHL at https://www.biodiversitylibrary.org. 